\title{
Nest-site selection by Eastern Osprey Pandion haliaetus cristatus in coastal south-eastern Queensland
}

\author{
Victoria K. Thomson*, Darryl Jones ${ }^{1}$ and Tim Stevens ${ }^{2}$ \\ 'School of Environment and Science, Environmental Futures Research Institute, Griffith University, Nathan QLD 4111, Australia \\ ${ }^{2}$ School of Environment and Science, Australian Rivers Institute, Griffith University, Southport QLD 4222, Australia \\ *Corresponding author. Email: vicky.thomson@griffithuni.edu.au
}

\begin{abstract}
Ospreys Pandion sp. are found worldwide, and are well known for nesting on anthropogenic structures, especially in highly developed urban coastal areas. In Australia, Eastern Ospreys $P$. haliaetus cristatus often nest on a variety of artificial structures, although little study has yet been conducted on this behaviour, particularly in rapidly urbanising areas such as south-eastern Queensland. We investigated the characteristics of Eastern Osprey nest-sites while surveying $\sim 200 \mathrm{~km}$ of coastline by boat. Two areas with contrasting urbanisation levels were inspected: the highly urbanised coastline fringing the Moreton Bay Marine Park (MBMP), and the less-developed coastal area within the Great Sandy Marine Park (GSMP). Nests in both areas had similar levels of exposure and aspect. In MBMP, significantly more nests were found on artificial structures, such as communications towers and navigation beacons, than in GSMP. The selection of these artificial structures potentially increases the risk of harm to the birds and may affect the functioning of the devices, with possible implications for human safety. With increasing human populations in south-eastern Queensland, the provision of alternative nesting options, such as strategically placed platforms, needs to be considered to ensure the continued breeding success of Ospreys in the region and to minimise conflict with humans.
\end{abstract}

\section{Introduction}

The Eastern Osprey Pandion haliaetus cristatus is distributed throughout coastal regions of Australia except for Victoria and Tasmania (Debus 2012). Unlike the Ospreys $P$. haliaetus of the Northern Hemisphere, Eastern Ospreys are non-migratory and typically maintain a homerange, which includes the nest-site, throughout the year (Clancy 1989; Bischoff 2001; Dennis 2007a; Debus 2012).

Typically, Eastern Ospreys nest on cliffs or in large trees (living or dead) that are usually in exposed locations with clear views to water (Debus 2012). As with Northern Hemisphere Ospreys, they also readily nest on artificial structures and are the only Australian coastal bird of prey to regularly do so (Marchant \& Higgins 1993). In the United States of America, the construction of nesting platforms became an important recovery and management practice following the decline of the Osprey in the 1960s from eggshell thinning caused by pesticides (Spitzer 1980; Bierregaard et al. 2014). In the Northern Hemisphere, Ospreys appear to be more likely to use structures for nesting in areas with higher levels of human development (Henny et al. 2010) and their productivity may benefit by doing so (Canal et al. 2018), but this phenomenon has so far received little research attention in Australia.

Eastern Osprey populations continue to decline in South Australia (Dennis 2007b; Dennis et al. 2011; Dennis \& Clancy 2014; Detmar \& Dennis 2018), where the species is listed as Endangered (Government of South Australia 2018). These declines have been attributed to the spread of urbanisation and subsequent loss of habitat (Dennis 2007a; Dennis \& Clancy 2014; T. Dennis pers. comm.). The South Australian coastline lacks coastal forest and is comprised of cliffs and narrow sandy beaches with local Eastern Ospreys often nesting on cliffs, small rocky stacks or on artificial structures (see Dennis \& Baxter 2006;
Dennis 2007b; Dennis et al. 2011). In contrast, the Eastern Osprey is listed as of Least Concern in Queensland (Queensland Government 2018) despite occurring in one of the country's fastest growing regions that has suffered significant habitat loss and degradation (Douglas et al. 2003; Morelli \& Gasparon 2014). Here the coastline is bordered by large sand islands and sheltered estuaries fully or partly protected within national parks (DES 2018). Although nesting platforms have been provided for Eastern Ospreys in numerous locations in this region, their utilisation has not been documented systematically.

Compared with other coastal birds of prey, Eastern Ospreys appear to be relatively tolerant of human activity and disturbances (Poole 1989; Dennis et al. 2011), one of the fundamental traits associated with successful exploitation of human-dominated landscapes (Chace \& Walsh 2006). The Eastern Osprey is commonly seen throughout south-eastern Queensland, nesting in both heavily urbanised areas and natural landscapes with virtually no human presence (VKT pers. obs.). This gradient of disturbance provides an excellent opportunity for investigating the selection of nest-sites with respect to varying levels of urbanisation.

Characteristics of natural nest-sites used by Eastern Ospreys are well documented but mainly limited to basic features such as substrate type (e.g. tree, cliff etc.), height above ground and tree dimensions (Marchant \& Higgins 1993; Debus 2012). Nest-site parameters have been investigated in some detail for three of the four coastal species (Eastern Osprey, White-bellied Sea-Eagle Haliaeetus leucogaster and Brahminy Kite Haliastur indus, but not Whistling Kite Haliastur sphenurus) found in the region. The features most commonly reported include type of structure, tree species, height of nest above the ground, distance to waterbodies and level of human disturbance (see Bischoff 2001; Sivakumar \& Jayabalan 2004; Lutter 
et al. 2006; Corbett \& Hertog 2011; Indrayanto et al. 2011; Rourke \& Debus 2016). Sometimes, elevation above sea-level and nest aspect (direction that nest faces) have also been included (e.g. Clancy 1989; Thurstans 2009; O'Donnell \& Debus 2012). However, comprehensive information remains underreported and has rarely been extensively explored, though Thurstans (2009) investigated nest-site variables of the White-bellied SeaEagle in Tasmania.

This study investigated the characteristics of nest-sites of Eastern Ospreys in two distinct areas within coastal southeastern Queensland: Great Sandy Marine Park (GSMP) and Moreton Bay Marine Park (MBMP), to determine the level of utilisation of artificial nesting structures in urban and non-urban environments. These structures include nesting platforms intentionally constructed for use by Ospreys and other structures used opportunistically (e.g. navigation beacons). This work will improve our understanding of the requirements for successful breeding of this bird in southeastern Queensland, where it appears to be persisting despite high levels of urbanisation. This is particularly relevant for MBMP and GSMP authorities, as protected areas have been shown to benefit Osprey productivity in Germany (Canal et al. 2018). In turn, this should inform decisions by local authorities in selecting locations for future artificial nest structures.

\section{Study site and methods}

\section{Survey area}

Two large areas of coastal estuary with varying urbanisation levels were surveyed in south-eastern Queensland: GSMP and MBMP (Figure 1). These are large coastal bays enclosed by large sand islands and both are dominated by similar vegetation (DES 2018). MBMP is located adjacent to Queensland's capital city of Brisbane, supporting 2.4 million people, and the City of Gold Coast, supporting $\sim 570,000$ people (Australian Bureau of Statistics 2018a, 2019). This region has experienced rapid urbanisation, with an annual population growth of $2.3 \%$ for Brisbane and $2.8 \%$ for the Gold Coast/Tweed Heads region from 2001 to

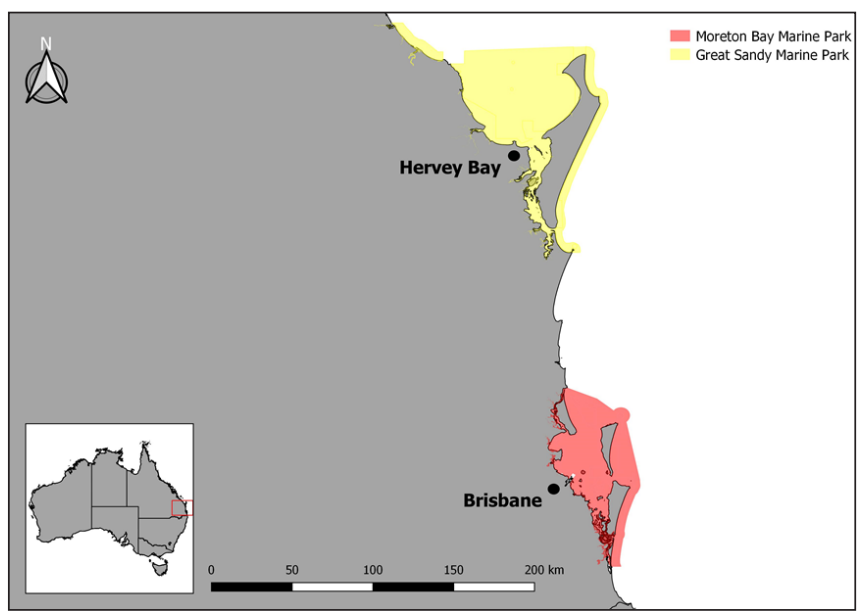

Figure 1. Boundaries of Great Sandy Marine Park and Moreton Bay Marine Park, south-eastern Queensland.
2011 (Dedekorkut-Howes et al. 2016), and includes many high-rise buildings, a cruise-ship terminal, two international airports and a major shipping port. In contrast, GSMP is adjacent to the small coastal city of Hervey Bay, housing $\sim 54,000$ people (Australian Bureau of Statistics 2018b), has no high-rise buildings and only a small local airport, and its boat traffic is dominated by the whale-watching tourism industry.

Most raptors tend to have large home-ranges (Peery 2000 ), so a large area of coastal habitat was required to provide adequate survey coverage in both subregions. As a consequence, 200 linear kilometres of coastline were surveyed in both MBMP and GSMP (Figures 2-3).

\section{Survey methods}

Surveys were conducted by boat (4-m-long aluminium boat) travelling at $\sim 6$ knots at high tide. All observations were made by VKT using $10 \times 50$ binoculars and long-lens photography (70-200 mm). The surveys encompassed similar habitat in both locations, incorporating the sheltered (western) side of the large sand islands to seaward, the eastern coastline of the adjacent mainland,

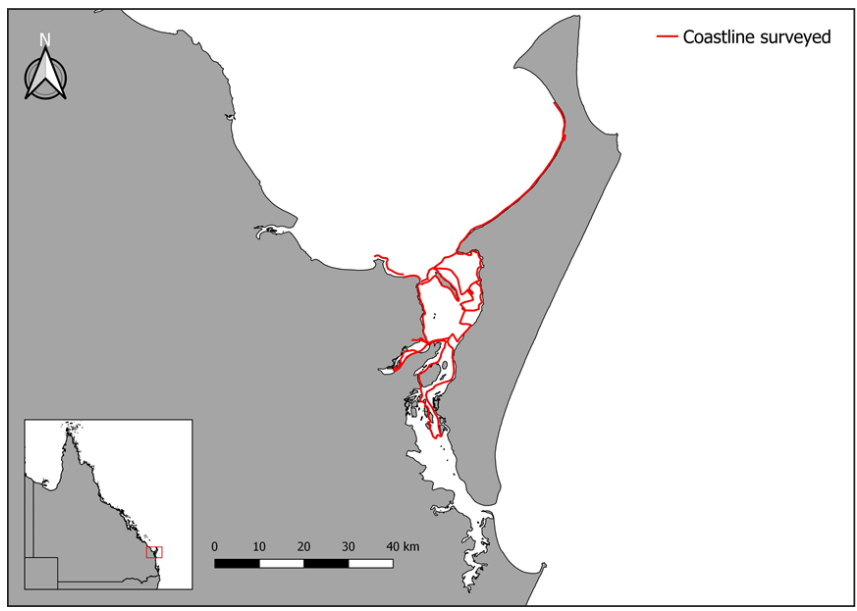

Figure 2. Survey transects undertaken by boat along the Great Sandy Marine Park coastline, which included the western shoreline of Fraser Island (K'gari).

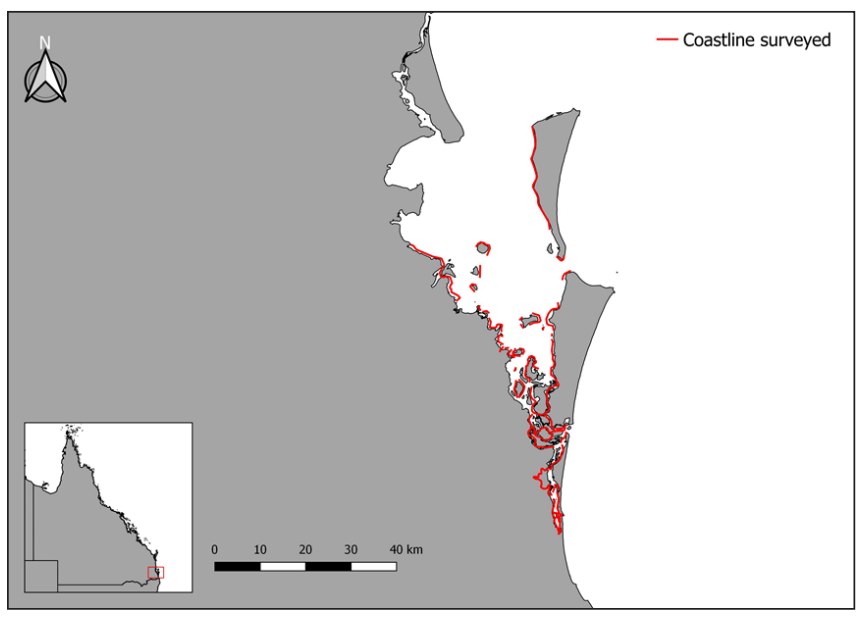

Figure 3. Survey transects undertaken by boat along the Moreton Bay Marine Park coastline, which included the western shorelines of Moreton Island (Moorgumpin) and North Stradbroke Island (Minjerribah). 
and circumnavigation of the numerous small islands in both marine parks. Gaps in the mapped transect lines (see Figures 2-3) indicate locations where the water was too shallow to survey by boat. Because of the nature of the survey areas, larger areas of mangrove habitat were surveyed in MBMP than in GSMP. Data were collected early in the 2018 breeding season (July), to ensure that any active nests had a brooding bird present and could thus be identified as Eastern Osprey nests. Surveys were conducted at high tide during the day in all weather (with the exception of strong winds $>10$ knots, for researcher safety) during 4-10 hours per day, depending on travel time and tide accessibility, across a period of 11 days.

For each nest, the following variables were recorded: location (GPS coordinates), supporting structure type [artificial (e.g. navigation beacon, power/communications tower, platform) or natural (e.g. living or dead tree, including tree species where possible)], groundcover underneath nest (generalised as vegetation type by researchers), height (measured with a Nikon Forestry 550 rangefinder and recorded as height of nest above high-tide level, as often the height of a nest above the ground could not be determined because of sloping terrain or limits to approach distance), aspect (the most direct path to water was considered to be the direction that the nest was facing), and exposure level [determined by researchers as high (nest at or very close to top of nesting structure, with little to no cover or screening foliage, and highly visible), medium (nest with partial foliage cover, and slightly less visible) or low (nest low in canopy, with much foliage surrounding it and therefore not easily detectable)].

In addition, all navigation beacons within the survey transects were assessed as either occupied by an Osprey nest or vacant, and nests were recorded as active or not active. For both parks, the number of nests on artificial and natural structures, the groundcover type below each nest, nest aspect, and especially the number of nests on navigation beacons were compared using chi-square tests. Specific locations of the nests are deliberately not reported here or mapped to prevent possible human interference.

\section{Results}

\section{Artificial versus natural structures}

A total of 32 active Eastern Osprey nests was detected during the study. There were significantly more nests on artificial structures in MBMP than in GSMP $(P<0.05$, $\chi^{2}=7.04$, df $=1$ ), with the two parks showing contrasting trends: $75 \%$ of nests in GSMP were on natural structures and $75 \%$ of those in MBMP were on artificial structures. More nests were found in MBMP than in GSMP (Table 1).

\section{Artificial structures}

The majority of Eastern Osprey nests on artificial structures were on power/communication towers (mobile telephone, satellite, radio and powerline), with $28 \%$ of all nests in MBMP on these structures. Of the nests on natural structures (trees only), the majority in GSMP were in living trees, whereas in MBMP all such nests were in dead trees (Figure 4).

Table 1. Number and percentage of Eastern Osprey nests found on natural and artificial structures in Great Sandy Marine Park (GSMP) and Moreton Bay Marine Park (MBMP).

\begin{tabular}{lccc}
\hline & GSMP & MBMP & Total \\
\hline Natural structures & $9(75 \%)$ & $5(25 \%)$ & $14(44 \%)$ \\
Artificial structures & $3(25 \%)$ & $15(75 \%)$ & $18(56 \%)$ \\
Total & 12 & $\mathbf{2 0}$ & 32 \\
\hline
\end{tabular}

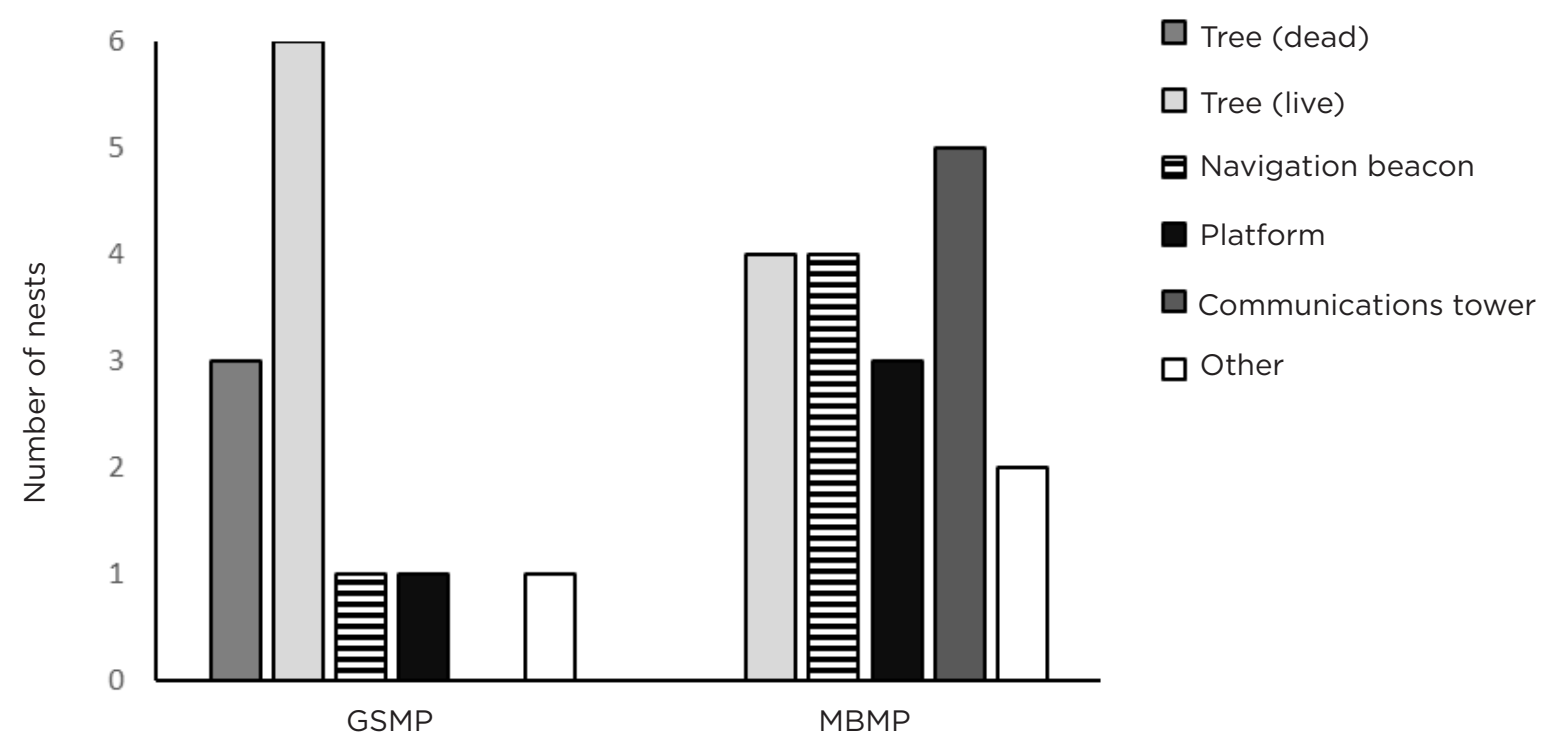

Figure 4. Number of Eastern Osprey nests on different structures in Great Sandy Marine Park (GSMP) and Moreton Bay Marine Park (MBMP). Other nest structures were a ship lift, a mining ore-conveyor and an art sculpture. 


\section{Navigation beacons}

In total, 660 navigation beacons were surveyed, 82 in GSMP and 578 in MBMP. Although similar survey areas were covered, there were many more navigation beacons in MBMP. In GSMP, 81 beacons had no evidence of an Eastern Osprey nest, and only one had an active nest. In MBMP, 571 beacons had no evidence of an Osprey nest, and seven had nests, with five of these being active $(1 \%$ of beacons in both parks supported active nests). There was no significant difference in the number of active nests on beacons between these two parks $\left(P>0.05, \chi^{2}=4.27 \mathrm{E}-05\right.$, df = 1).

\section{Nest parameters}

On average, Eastern Osprey nests (on both artificial and natural structures) were higher above high-tide level in MBMP (range 4.0-65.6 m) than GSMP (range 5.2-29.2 m) (Figure 5).

Every active nest had a high exposure, except for three nests in GSMP (all on natural structures), of which two had medium exposure and one low exposure. In both parks, no clear nest aspect could be determined in most cases because of the high level of nest exposure (e.g. on navigation beacons).

There was a significant difference between parks in groundcover below nest-sites $\left(P<0.05, \chi^{2}=15.35\right.$, $\mathrm{df}=7$ ). In GSMP, most nests were above a sandy substrate, whereas in MBMP most were over water and none were over a sandy substrate (Figure 6). One nest in MBMP was omitted from our analysis as the groundcover beneath it could not be determined from the angle of the survey boat.

\section{Discussion}

This extensive survey of two large and similarly sized coastal areas with contrasting levels of human development revealed significant differences in the characteristics of Eastern Osprey nest-sites. More active nests were

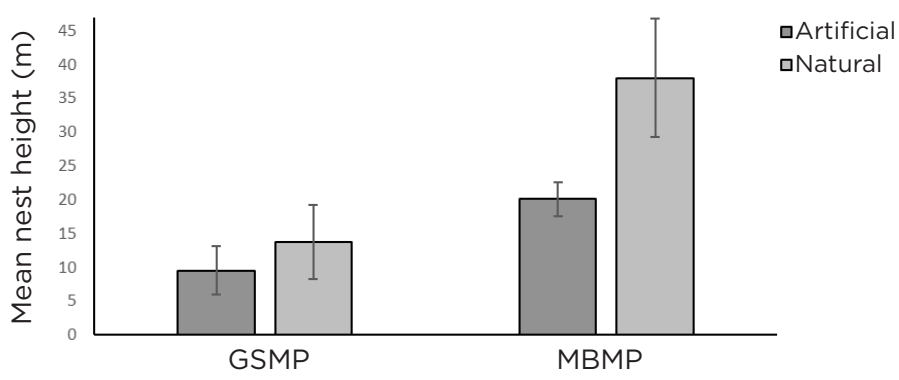

Figure 5. Mean height (to high-tide water level) of Eastern Osprey nests on artificial and natural structures in Great Sandy Marine Park (GSMP) and Moreton Bay Marine Park (MBMP).

found in MBMP than GSMP over the early stages of the 2018 breeding season. Although Ospreys nested on artificial structures in both marine parks, significantly more of the nests $(75 \%)$ were on these in MBMP than in GSMP, which showed the opposite trend $(75 \%$ on natural structures). These results are similar to observations on Northern Hemisphere Ospreys, which appear to nest more frequently on artificial structures in areas with higher levels of development (Henny et al. 2010).

It is clear that in south-eastern Queensland Eastern Ospreys favour nesting positions with high exposure, but which are not necessarily high above the water. The majority of nests in both parks had a high exposure level, faced no preferred direction, and were 4.0-65.6 m above the water. Nests in MBMP were higher on average than those in GSMP although this was measured as distance above the water not the ground as the latter was very difficult to measure from a boat. The high topography of Moreton Island (Moorgumpin), which is surrounded by MBMP, might have contributed to this pattern, and the difference seen between parks may not be representative of the nesting choice of this species throughout its range. Nests in MBMP were predominantly over water, whereas those in GSMP were mostly over sand. As most nests in MBMP were on navigation beacons and power/ communications towers (including towers over water), this is not surprising and may represent a choice of available nesting structures rather than the substrate on which these were erected.

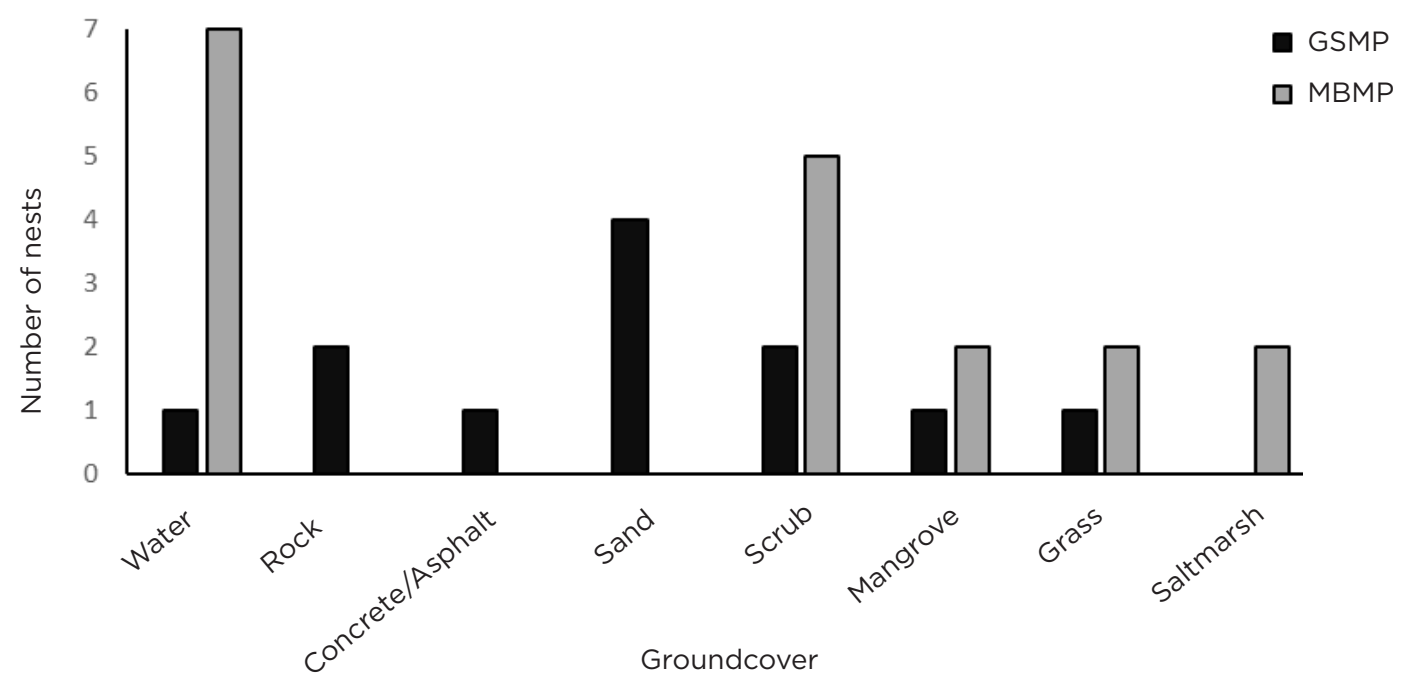

Figure 6. Groundcover below Eastern Osprey nests in Great Sandy Marine Park (GSMP) and Moreton Bay Marine Park (MBMP). 
More navigation beacons were present in MBMP (578) than GSMP (82), with $\sim 1 \%$ of the beacons supporting a nest in both parks. This suggests that the use of these structures by the Ospreys is simply opportunistic and is based on their availability in the landscape.

Eastern Ospreys nesting in MBMP appeared to favour power/communications towers and navigation beacons for nesting, which does pose problems for both the birds and the public. Birds nesting on communications towers may be subject to radiation toxicity (Washburn 2014) and fatal collision (W. Riddell pers. comm.). Birds nesting on navigation beacons may also represent a significant risk for vessels if their visibility and that of navigation lights are impaired by the presence of nesting material.

It is possible that Eastern Ospreys may compete for nesting space with other coastal raptor species, particularly White-bellied Sea-Eagles, which also utilise large tall trees such as Eucalyptus spp. for nesting (Debus 2017). The propensity of Ospreys to nest on artificial structures may reduce this competition in MBMP. Fraser Island (K'gari), surrounded by GSMP, is a significantly larger area than Moreton Island (the largest island surrounded by MBMP: DES 2018), and may provide more nesting sites for both species, possibly minimising any competition between species. Confirming this would, however, require further study.

Interestingly, nests in both parks had similar nest parameters such as exposure level and aspect, indicating that a high level of exposure with good clear access to water is of particular importance for Eastern Ospreys nesting in both urban and non-urban environments in south-eastern Queensland. Perhaps these factors are the most important aspect for nest choice, as disturbance factors (such as nesting on a moving ship lift and loud mining equipment or flashing beacon lights) are present in nesting locations in both parks.

During a 9-year study in Germany, productivity of Northern Hemisphere Ospreys was shown to increase with the use of artificial nesting substrates, and was also higher in protected than non-protected areas (Canal et al. 2018). These authors attributed this higher productivity to the use of artificial nesting, possibly from a reduction in natural predation pressures, and it is likely that these structures may similarly benefit the Australian subspecies. As Eastern Ospreys in the present study nested primarily on artificial structures in MBMP (particularly communication towers, powerline structures and navigation beacons), it is important to consider solutions for the birds' safety as well as that of the local community and boat craft. It is therefore suggested that local councils consider installing alternative artificial nesting platforms throughout MBMP and that physical deterrents are added to favoured structures. Nesting platforms were critical in the recovery of Osprey populations in North America (Bierregaard et al. 2014), and as Eastern Ospreys in south-eastern Queensland appear to use nesting platforms readily, strategically placed nesting platforms across the parks should be considered. As the human population in south-eastern Queensland continues to expand rapidly (Dedekorkut-Howes et al. 2016), it is likely that additional communications towers will be erected to keep up with technological demands. It is therefore important to maintain suitable breeding facilities not only for the continued persistence of the Eastern Osprey in the region, but also for other coastal raptor species with which it competes for nesting space, such as the White-bellied Sea-Eagle, Brahminy Kite and Whistling Kite, and to avoid conflict with the ever-growing human population.

\section{Acknowledgements}

We wish to acknowledge the traditional custodians of the lands on which this study was conducted, specifically the Butchulla and Quandamooka people and their Elders past and present. This study was conducted under a Queensland Government National Parks Sports and Racing permit (QS2018/MAN466).

\section{References}

Australian Bureau of Statistics (2018a). 2016 Census Quickstats Greater Brisbane. Australian Bureau of Statistics. Available online: http://quickstats.censusdata. abs.gov.au/census_services/getproduct/census/2016/ quickstat/3GBRI?opendocument (retrieved 26 March 2018).

Australian Bureau of Statistics (2018b). 2016 Census Quickstats Hervey Bay State Electoral Division. Australian Bureau of Statistics. Available online: http://quickstats.censusdata.abs. gov.au/census_services/getproduct/census/2016/ quickstat/ SED30036?opendocument (retrieved 26 March 2018).

Australian Bureau of Statistics (2019). 2016 Census Quickstats Gold Coast-Tweed Heads. Australian Bureau of Statistics. Available online: http://quickstats.censusdata. abs.gov.au/census_services/getproduct/census/2016/ quickstat/3006?opendocument (retrieved 25 February 2019).

Bierregaard, R.O., Poole, A.F. \& Washburn, B.E. (2014). Ospreys (Pandion haliaetus) in the 21st century: Populations, migration, management, and research priorities. Journal of Raptor Research 48, 301-308.

Bischoff, T. (2001). Aspects of breeding of the Osprey Pandion haliaetus on the mid-north coast of New South Wales. Australian Bird Watcher 19, 88-93.

Canal, D., Morandini, V., Martín, B., Langgemach, T., Muriel, R., de Lucas, M. \& Ferrer, M. (2018). Productivity is related to nest site protection and nesting substrate in a German Osprey population. Journal of Ornithology 159, 265-273.

Chace, J.F. \& Walsh, J.J. (2006). Urban effects on native avifauna: A review. Landscape and Urban Planning 74, 46-69.

Clancy, G. (1989). A survey of breeding Ospreys (Pandion haliaetus) in north-eastern coastal New South Wales, 1980 to 1982. Corella 13, 9-14.

Corbett, L. \& Hertog, T. (2011). Diet and breeding of White-bellied Sea-Eagles Haliaeetus leucogaster in subtropical river habitats in the Northern Territory, Australia. Corella 35, 41-48.

Debus, S.J.S. (2012). Birds of Prey of Australia. 2nd edn. CSIRO Publishing, Melbourne.

Debus, S.J.S. (2017). Australasian Eagles and Eagle-like Birds. CSIRO Publishing, Melbourne.

Dedekorkut-Howes, A., Bosman, C. \& Leach, A. (2016). Considering the Gold Coast. In: Bosman, C., DedekorkutHowes, A. \& Leach, A. (Eds). Off the Plan: The Urbanisation of the Gold Coast, pp. 1-16, CSIRO Publishing, Melbourne.

Dennis, T.E. (2007a). Reproductive activity in the Osprey (Pandion haliaetus) on Kangaroo Island, South Australia. Emu 107, 300-307.

Dennis, T.E. (2007b). Distribution and status of the Osprey (Pandion haliaetus) in South Australia. Emu 107, 294-299.

Dennis, T.E. \& Baxter, C. (2006). The status of the White-bellied Sea-Eagle and Osprey on Kangaroo Island in 2005. South Australian Ornithologist 35, 47-51.

Dennis, T.E. \& Clancy, G.P. (2014). The status of the Osprey (Pandion haliaetus cristatus) in Australia. Journal of Raptor Research 48, 408-414.

Dennis, T.E., Detmar, S., Brooks, A. \& Dennis, H. (2011). Distribution and status of White-bellied Sea-Eagle, Haliaeetus leucogaster, and Eastern Osprey, Pandion cristatus, populations in South Australia. South Australian Ornithologist 37, 1-16. 
DES (2018). Habitat Specifics for Moreton Bay Marine Park and Great Sandy Marine Park. Department of Environment and Science. Available online: https://parks.des.qld.gov.au/ (retrieved 25 April 2018).

Detmar, S.A. \& Dennis, T.E. (2018). A review of Osprey distribution and population stability in South Australia. South Australian Ornithologist 43, 38-54.

Douglas, G., Palmer, M. \& Caitcheon, G. (2003). The provenance of sediments in Moreton Bay, Australia: A synthesis of major, trace element and $\mathrm{Sr}-\mathrm{Nd}-\mathrm{Pb}$ isotopic geochemistry, modelling and landscape analysis. Hydrobiologia 494, 145-152.

Government of South Australia (2018). South Australia's National Parks and Wildlife Act 1972. Attorney-General's Department. Legislation Revision and Publication Act 2002. Available online: www.legislation.sa.gov.au/LZ/C/A/NATIONAL\%20PARKS\%20 AND\%20WILDLIFE\%20ACT\%201972.aspx (retrieved 22 January 2019).

Henny, C.J., Grove, R.A., Kaiser, J.L. \& Johnson, B.L. (2010). North American osprey populations and contaminants: Historic and contemporary perspectives. Journal of Toxicology and Environmental Health, Part B 13, 579-603.

Indrayanto, P., Latip, N.S.A. \& Sah, S.A.M. (2011). Observations on the nesting behaviour of the Brahminy Kite Haliastur indus on Penang Island, Malaysia. Australian Field Ornithology 28, 38-46.

Lutter, H., McGrath, M.B., McGrath, M.A. \& Debus, S.J.S. (2006). Observations on nesting Brahminy Kites Haliastur indus in northern New South Wales. Australian Field Ornithology 23, 177-183.

Marchant, S. \& Higgins, P.J. (Eds) (1993). Handbook of Australian, New Zealand \& Antarctic Birds, Volume 2: Raptors to Lapwings. Oxford University Press, Melbourne.

Morelli, G. \& Gasparon, M. (2014). Metal contamination of estuarine intertidal sediments of Moreton Bay, Australia. Marine Pollution Bulletin 89, 435-443.
O'Donnell, W.B. \& Debus, S.J.S. (2012). Nest-sites and foraging of the White-bellied Sea-Eagle Haliaeetus leucogaster on the subtropical eastern coast of Australia. Australian Field Ornithology 29, 149-159.

Peery, M.Z. (2000). Factors affecting interspecies variation in home-range size of raptors. Auk 117, 511-517.

Poole, A.F. (1989). Ospreys: A Natural and Unnatural History. Cambridge University Press, Cambridge, UK.

Queensland Government (2018). Nature Conservation (Wildlife) Regulation 2006. Queensland Legislation. Available online: www.legislation.qld.gov.au/view/html/inforce/current/sl-20060206 (retrieved 11 April 2018).

Rourke, J. \& Debus, S. (2016). The breeding cycle of a pair of Brahminy Kites Haliastur indus in New South Wales. Australian Field Ornithology 33, 151-155.

Sivakumar, S. \& Jayabalan, J.A. (2004). Observations on the breeding biology of Brahminy Kite Haliastur indus in Cauvery Delta region. Zoo's Print Journal 19, 1472-1474.

Spitzer, P. (1980). Dynamics of a Discrete Coastal Breeding Population of Ospreys in the Northeastern United States During the Period of Decline and Recovery, 1969-1978. PhD thesis. Cornell University, New York.

Thurstans, S. (2009). Modelling the nesting habitat of the Whitebellied Sea-Eagle Haliaeetus leucogaster in Tasmania. Corella 33, 51-65.

Washburn, B.E. (2014). Human-Osprey conflicts: Industry, utilities, communication, and transportation. Journal of Raptor Research 48, 387-395.

Received 20 December 2018, accepted 24 July 2019, published online 17 October 2019 